\title{
Carbonization techniques and wood species influence quality attributes of charcoals produced from industrial sawmill residues in Eastern Cameroon
}

\begin{abstract}
Joseph Zово Мғомо ${ }^{1}$
Achille Bernard BIwoLÉ ${ }^{1}$

Gilbert Tsoh EKASSI ${ }^{1}$

Didier HUBERT ${ }^{2}$

Hugues DuCENNE ${ }^{2}$

Jean Gaston TAMBA ${ }^{3}$

Ruben MOUANGUE ${ }^{4}$
\end{abstract}

Evariste FEdoung FongzossiE ${ }^{1}$

\section{${ }^{1}$ University of Douala}

Advanced Teacher's Training College for Technical Education

PO Box 1872, Douala

Cameroon

${ }^{2}$ German Development Cooperation Program for the Implementation of the Rural Development Strategy Forest-Environment Programme Eco-Consulting Group PO Box 7814, Yaoundé

Cameroon

\section{${ }^{3}$ University of Douala} University Institute of Technology PO Box 8698, Douala

Cameroon

${ }^{4}$ University of Ngaoundéré University Institute of Technology PO Box 454, Ngaoundéré Cameroon

Auteurs correspondants / Corresponding authors: Joseph ZOBO MFOMO

- zobo mfomo@yahoo.fr Ruben MOUANGUE

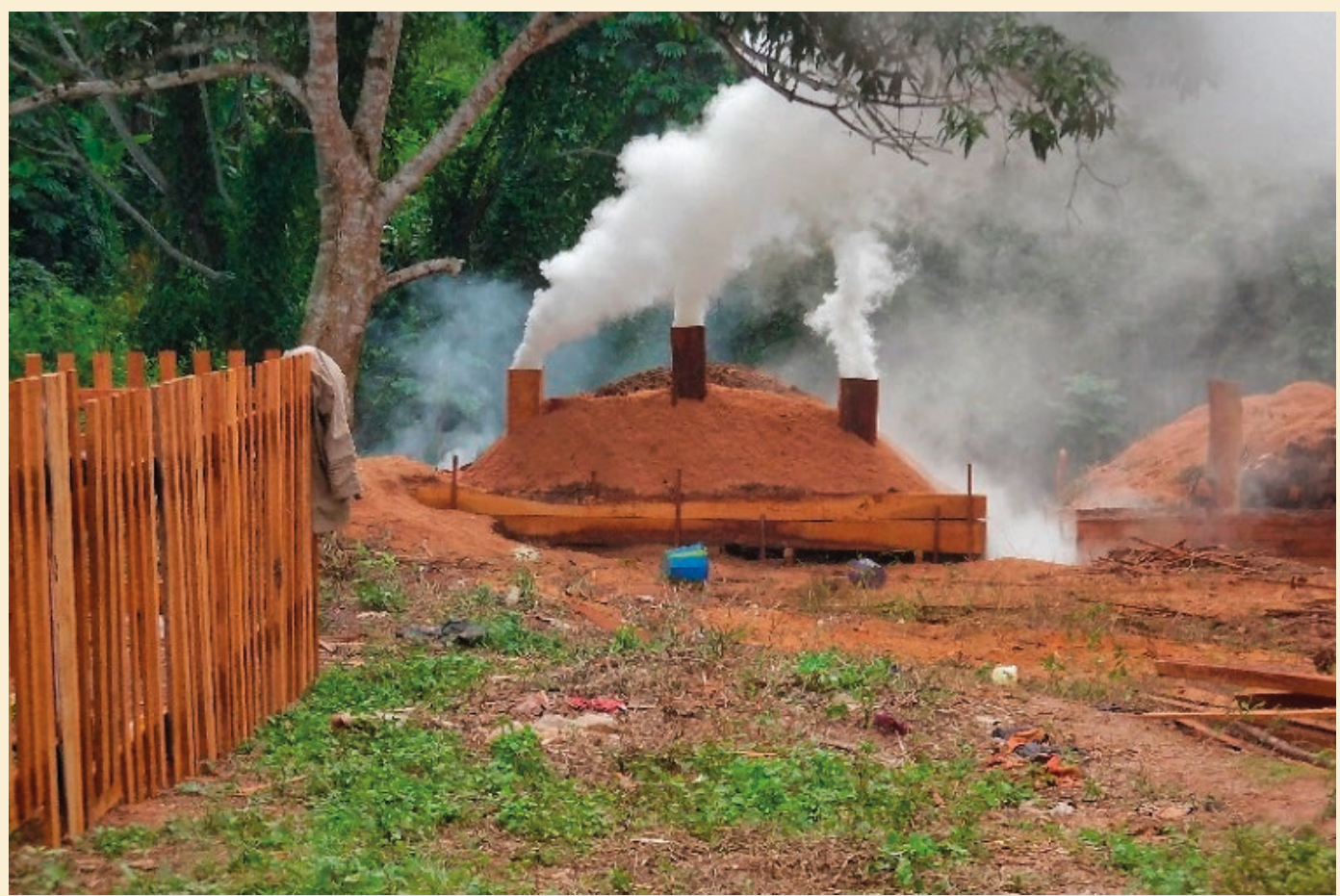

-r mouangue@yahoo.fr

Improved traditional kiln commonly used by charcoal producers in the eastern region of Cameroon. Photo D. Hubert.

Doi : 10.19182/bft2020.345.a31831 - Droit d'auteur @ 2020, Bois et Forêts des Tropiques - @ Cirad - Date de soumission : 21 décembre 2019 ; date d'acceptation : 23 juin 2020 ; date de publication : $1^{\text {er }}$ novembre 2020.
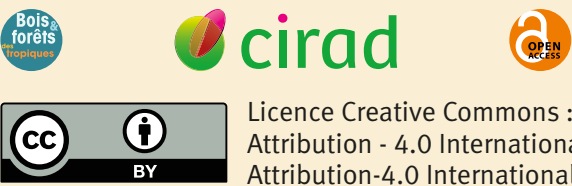

Citer l'article / To cite the article

Zobo Mfomo J., Biwolé A. B., Fedoung Fongzossie E., Ekassi G. T., Hubert D., Ducenne H., Tamba J. G., Mouangue R., 2020. Carbonization techniques and wood species influence quality attributes of charcoals produced from industrial sawmill residues in Eastern Cameroon. Bois et Forêts des Tropiques, 345 : 63-72. Doi: https://doi.org/10.19182/bft2020.345.a31831 


\section{RÉSUMÉ}

Influence de la technique de carbonisation et de l'essence de bois sur la qualité des charbons produits à partir des résidus de sciages industriels à l'Est du Cameroun

Le Cameroun exploite un volume considérable de bois rond chaque année, dont une infime partie est utilisée pour la fabrication de produits manufacturés. Depuis quelques décennies, des initiatives se développent autour de scieries industrielles, surtout dans la région de l'Est, pour valoriser la biomasse résiduelle. Cependant, l'utilisation non différenciée des résidus issus d'essences différentes donne souvent des produits au potentiel énergétique variable et pas toujours appréciés des consommateurs. D'autre part, les caractéristiques physico-chimiques de ces charbons de bois sont inconnues, de même que les facteurs qui influencent leur qualité. La présente étude avait pour objectif d'évaluer la variabilité des propriétés physico-chimiques du charbon de bois produit avec des résidus du sciage industriel à l'Est du Cameroun, à l'aide de différentes techniques de carbonisation. Trois essences de bois, ayous, fraké et movingui, et trois types de fours (traditionnel, traditionnel amélioré et casamançais) ont été utilisés. Pour chaque essence, trois fagots de cinq morceaux de bois chacun ont été préparés, avec un taux d'humidité initial variant de $28 \%$ à $36 \%$. Les propriétés physico-chimiques déterminées étaient le taux d'humidité, la densité apparente, les teneurs en matières volatiles, en carbone fixe et en cendres, et le pouvoir calorifique supérieur (PCS). Nos résultats montrent que les propriétés du charbon de bois varient selon l'essence et les types de fours utilisés. Le charbon de bois de movingui, dont la densité est la plus élevée $\left(0,73 \mathrm{~g} / \mathrm{cm}^{3}\right)$, présente le plus faible taux d'humidité $(4,03 \%)$ et la densité apparente la plus élevée $\left(0,42 \mathrm{~g} / \mathrm{cm}^{3}\right)$. Les teneurs les plus faibles en matières volatiles $(20,32 \%)$ et en cendres $(1,27 \%)$ ont également été obtenues avec cette essence, ainsi que la teneur la plus élevée en carbone fixe $(74,95 \%)$. Toutes ces valeurs pour le charbon de bois de movingui ont été obtenues avec la meule casamançaise. Cependant, le PCS le plus élevé $(32,51 \mathrm{MJ} / \mathrm{kg})$ a été obtenu avec le charbon de bois d'ayous produit dans une charbonnière Casamance. La comparaison des trois types de fours utilisés montre que les meilleures propriétés physico-chimiques s'obtiennent avec la meule casamançaise. Tous les charbons de bois analysés sont conformes aux normes FAO pour la cuisson des aliments. Le PCS le plus élevé obtenu avec le charbon de bois d'ayous indique sa forte capacité à émettre une grande quantité d'énergie thermique au cours de la combustion tout comme un bois dur.

Mots-clés : charbon de bois, techniques de carbonisation, propriétés physico-chimiques, résidus de scierie industrielle, Est-Cameroun.

\section{ABSTRACT}

\section{Carbonization techniques and wood species influence quality attributes of charcoals produced from industrial sawmill residues in Eastern Cameroon}

Cameroon harvests a considerable volume of round wood each year, only a small part of which is used for manufactured products. In recent decades, various charcoal-making initiatives have emerged around industrial timber-processing units, particularly in the eastern region, in order to develop a market for residual biomass. However, the undifferentiated use of these residues obtained from different species often results in products with varying energy potential that are not always appreciated by consumers. Moreover, the physical and chemical characteristics of the charcoal produced are unknown, as are the factors that influence its quality. The aim of this study was to assess the variability of the physical and chemical properties of charcoal produced from industrial sawmill residues in the eastern region of Cameroon using different carbonization techniques. Three wood species, Ayous, Frake and Movingui, and three types of kilns (traditional, improved traditional and Casamance system) were used. For each species, three bundles of five pieces of wood each were prepared, with an initial moisture content ranging from $28 \%$ to $36 \%$. The physi$\mathrm{cal}$ and chemical properties determined were moisture content, apparent density, volatile matter content, fixed carbon content, ash content and Higher Heating Value (HHV). Our results showed that the charcoal properties varied depending on the wood species and types of kilns used. Movingui, with the highest density $\left(0.73 \mathrm{~g} / \mathrm{cm}^{3}\right)$, produced charcoal with the lowest moisture content $(4.03 \%)$ and the highest apparent density $\left(0.42 \mathrm{~g} / \mathrm{cm}^{3}\right)$. The lowest volatile matter content $(20.32 \%)$, the lowest ash content (1.27\%) and the highest fixed carbon content (74.95\%) were also obtained with this species. All these values were obtained with Movingui charcoal produced with the Casamance system. However, the highest HHV $(32.51 \mathrm{MJ} / \mathrm{kg})$ was obtained with charcoal from Ayous, also produced with the Casamance system. On comparing the three charcoaling systems used, the Casamance model yielded the best physical and chemical charcoal properties. All the charcoals studied complied with FAO standards for cooking fuel. The highest HHV obtained with charcoal from Ayous hardwood shows its ability to release large amounts of thermal energy during combustion.

Keywords: charcoal, carbonization techniques, physico-chemical properties, industrial sawmill residues, Eastern Cameroon.

\section{E. Fedoung Fongzossie, G. T. EKassi, D. Hubert, H. Ducenne, J. G. TAmba, R. Mouangue}

\section{Las técnicas de carbonización y las especies de madera influyen en las propiedades cualitativas del carbón vegetal producido por los residuos de serrerías industriales en el este del Camerún}

El Camerún explota anualmente un volumen considerable de madera redonda, una pequeña parte de la cual se utiliza en productos manufacturados. En las últimas décadas se han desarrollado diferentes iniciativas de producción de carbón vegetal junto a las industrias de procesamiento de madera, especialmente en la región del este, para desarrollar un mercado para su biomasa residual. Sin embargo, el uso no diferenciado de estos residuos, obtenidos de diferentes especies, a menudo proporciona productos con potencial de energía variable, que no siempre son apreciados por los consumidores. Además, las características física y química de este carbón vegetal son desconocidas, así como los factores que influyen en su calidad. El objetivo de este estudio es evaluar la variabilidad de las propiedades físicas y químicas del carbón vegetal producido con residuos de serrería en la región este de Camerún, mediante diferentes técnicas de carbonización. Se utilizaron tres especies de madera, Ayous, Frake y Movingui, y tres tipos de hornos (tradicional, tradicional mejorado y sistema Casamance). Para cada especie, se prepararon tres haces de cinco piezas de madera cada uno, con un contenido inicial de humedad en el rango del 28 al $36 \%$. Las propiedades físicas y químicas determinadas eran la tasa de humedad, la densidad aparente, la cantidad de materia volátil, la cantidad de carbono fijado, la cantidad de ceniza y el poder calorífico superior (PCS). Nuestros resultados mostraron que las propiedades del carbón vegetal variaban en función de la especie de madera y de los tipos de horno utilizados. Movingui, con la densidad más elevada $\left(0,73 \mathrm{~g} / \mathrm{cm}^{3}\right)$, produjo carbón vegetal con la tasa de humedad más baja $(4,03 \%)$ y la densidad aparente más elevada $\left(0,42 \mathrm{~g} / \mathrm{cm}^{3}\right)$. La cantidad de materia volátil más baja (20,32\%), la cantidad de ceniza más baja (1,27\%) y la cantidad de carbono fijado más elevada $(74,95 \%)$ también se obtuvo con estas especies. Todos estos valores se consiguieron con el carbón vegetal de Movingui producido por el horno Casamance. Sin embargo, el PCS más elevado $(32,51 \mathrm{MJ} / \mathrm{kg})$ se obtuvo con carbón vegetal de Ayous producido en el horno Casamance. Comparando los tres tipos de horno utilizados, el horno Casamance proporcionó las mejores propiedades físicas y químicas del carbón. Todos los carbones vegetales estudiados cumplían los estándares FAO de combustible para cocción de alimentos. El PCS más elevado, obtenido con carbón vegetal de Ayous, muestra su capacidad para liberar grandes cantidades de energía térmica durante la combustión de madera dura.

Palabras clave: carbón vegetal, técnicas de carbonización, propiedades fisicoquímicas, residuos de serrería industrial, este de Camerún. 
Central Africa hosts a remarkable forest potential that significantly contributes to national economies (Nasi et al., 2012; Eba'a Atyi et al., 2013). The wood production capacity in Cameroon is estimated at 5 million cubic metres of standing timber per year, of which 2.97 million cubic metres represents the share of round wood harvested annually. However, only a small proportion of this harvested volume is processed, most of the residual biomass is being considered as unusable residues (FRM, 2018). Nowadays, the quantity of processed round wood in Cameroon is estimated at $891,000 \mathrm{~m}^{3} /$ year, representing a mass-yield (volume of products processed on the logs volume received at the factory) of only $30 \%$. This low material yield is mainly explained by the current industrial model, based on the export of primary processing products to markets with high quality requirements (FRM, 2018).

Paradoxically, the use of wood energy remains a major concern in large urban centres in Cameroon and other Central African countries, where it represents the main form of domestic energy (Marien et al., 2013). Indeed, faced with the difficulty to access the other forms of energy such as: fossil energy, hydroelectric energy, and alternative energies (solar, wind), wood consumption is increasing sharply in most countries in this region (Schure et al., 2010) and this trend will certainly continue to evolve in the coming decades due to demographic expansion. In Cameroon, where nearly $83 \%$ of the population depends on woody biomass as energy source, charcoal consumption is growing at a rate of 2.67\%/year (Eba'a Atyi et al., 2013).

Charcoal is currently one of the most sought-after fuels in urban centres in this country. This is due to its properties and various uses (Schure et al., 2012). Although several other techniques have been tested, including improved traditional kiln, Casamance kiln, metal kiln, Brazilian kiln, artisanal horn kiln, and buried industrial horn kiln (Nguenang and Ngo Badjeck, 2013; Tchouanti Nzali et al., 2019; Mouangue et al., 2020; Miguiri et al., 2020), charcoal production remains essentially archaic in Cameroon. It is mainly based on the use of traditional kilns which are practical and economically affordable, but with low mass-yield between 12 to $20 \%$ (FAO, 2017). However, there is no information on their properties as well as the impact of the carbonization techniques used for their production in the literature (Nguenang and Ngo Badjeck, 2013). The domestic charcoal quality is determined by its physical and chemical properties. According to FAO (FAO, 1985), charcoal of excellent quality has less than $10 \%$ of moisture content, 20 to $25 \%$ of volatile matter content, 75 to $80 \%$ of fixed carbon content, and 3 to $4 \%$ of ash content. Rosa et al. (2012) reported higher values of apparent density $\left(0.46 \mathrm{~g} / \mathrm{cm}^{3}\right)$, higher heating value (30.88 MJ/kg) and fixed carbon content (75 to $83 \%$ ), lower values of moisture content $(5.5 \%)$, volatile matter (15 to $23 \%$ ), and ash content ( 0.68 to $1.65 \%)$. There are studies indicating that, the properties of charcoal are influenced by the carbonization techniques (Assis et al., 2016) and the wood species used (Adegoke et al., 2014). Indeed, Adegoke et al. (2014) in Nigeria reported good combustion properties of charcoal from the sawmill residues of two low-density African species: Terminalia superba (higher heating value $=32.69 \mathrm{MJ} / \mathrm{kg}$ ) and Triplochiton sclorexylon (higher heating value $=32.79 \mathrm{MJ} / \mathrm{kg}$ ). Unfortunately, until date, few studies have been focused on the tropical species that are harvested from central Africa. Hence, the properties of charcoal produced from the sawmill residues are largely unknown. Yet, such information could help to better define the conditioning of these products and improve its access to new markets. There is therefore an urgent need to determine the properties of these charcoals and to evaluate the impact of carbonization techniques on the final products. It is in this perspective that the present work was carried out with the objective of assessing the physical and chemical properties of charcoal obtained from sawmill residues in the eastern region of Cameroon, and to analyse the influence of carbonization techniques on the final products.

\section{Materials and methods}

\section{Acquisition and preparation of charcoals}

Wood materials used for the production of charcoal were industrial sawmill residues collected from a wood-processing unit of a logging company (Société Industrielle de Mbang) located in the eastern region of Cameroon. This company has an agreement with charcoal producers to supply them with the sawmill residues necessary to produce charcoal. Three different types of kilns were used by these charcoal producers were selected as the carbonization technologies to be analysed (photos 1). They include the traditional kiln (TK), which is the most widely used by the charcoal producers, the improved traditional kiln (ITK) and the Casamance kiln (CK). A brief description of these three carbonization technologies is given in the following section.

Three wood bundles of five pieces, each of $700 \times 200 \times 20 \mathrm{~mm}$ and initial moisture contents ranging from $28 \%$ to $36 \%$ were placed in each kiln. Each bundle that was charred was made of one of the three species used: Ayous (Triplochiton scleroxylon), Frake (Terminalia superba) and Movingui (Distemonanthus benthamianus). Ayous and Frake are very light, soft and porous woods, while Movingui is a Medium-heavy wood. These species were chosen based on the availability of their sawmill residues in the processing unit during the study period (February-April 2018) and the traceability of the wood species processed in the processing unit. Eight samples of each bundle were randomly selected for physicochemical properties analysis (figure 1). Five of them were used to determine the physical properties. Each of these five samples were futher divided into two parts. One part was used for moisture content analysis, while the other one was use for the determination of the apparent density. The three remaining samples of each bundle were also taken 

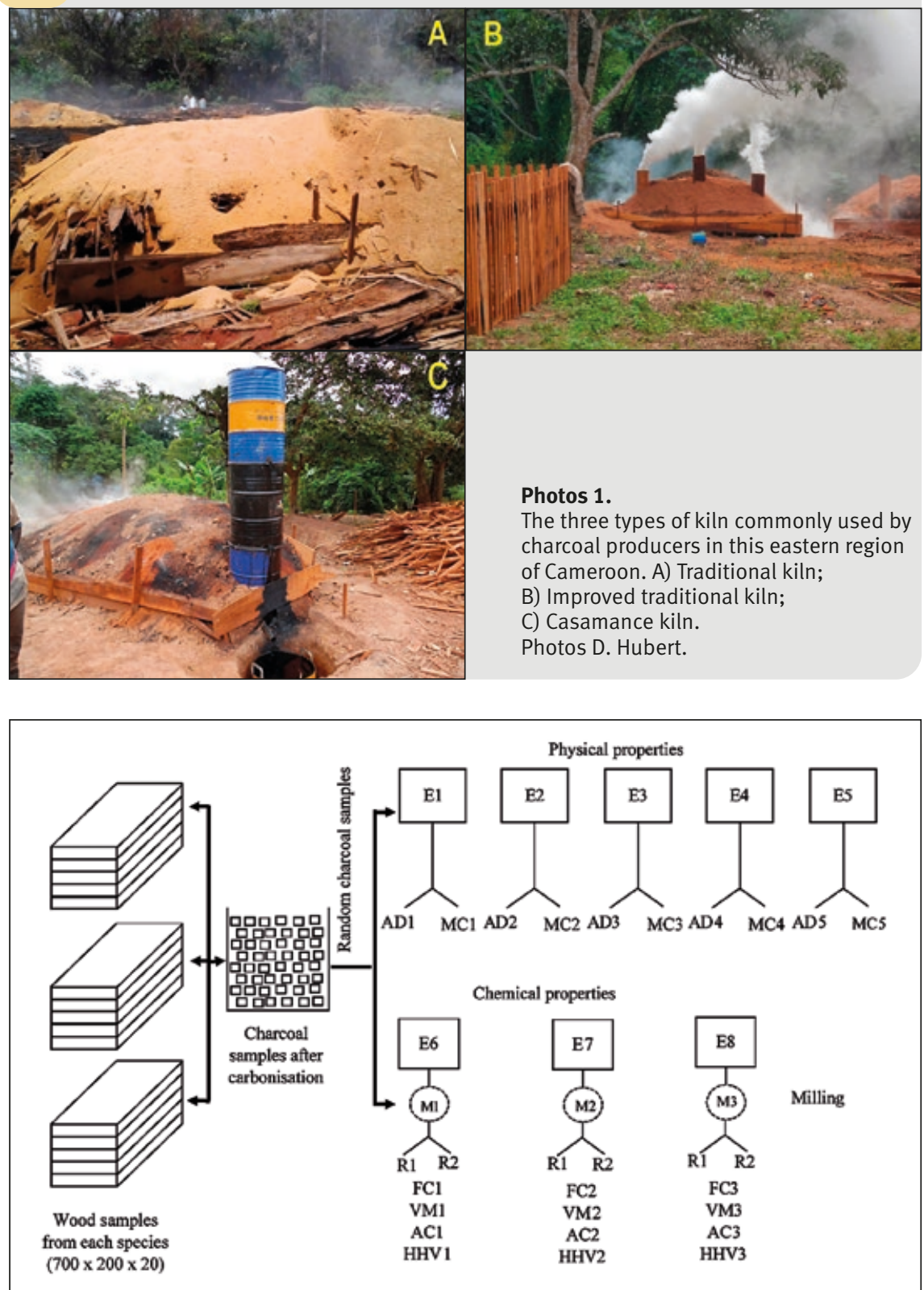

Figure 1.

Schematic illustration of sampling design from the wood to charcoal to laboratory. E1 to E5 are the six samples selected for the analysis of physical properties; E6 to E8 are three samples selected for chemical properties analysis. AD1 to AD5; MC1 to MC5; FC1 to FC3; VM1 to VM3, AC1 to AC3 and HHV1 to HHV3 corresponding to samples used to measure Apparent density, Moisture content, Fixed carbon, Volatile matter, Ash content and Higher heating value respectively.

M1 to M3 are the fraction of charcoal mill used for chemical analysis. R1 and R2 are the replicates of each sample used for chemical analysis.

\section{Descriptions of the charcoal production techniques studied}

\section{Traditional Kiln (TK)}

The most widely used kiln used in the eastern region of Cameroon is the traditional dome kiln. It is made from locally available materials. Wood residues collected from the wood processing units are perpendicularly arranged in the kiln. Then two successive layers of sawdust and earth respective are used to seal the kiln. A ventilation hole allows control and monitoring of the carbonization process. Depending on the size of the kiln, constant attention needs to be paid for the 3 to 15 days after firing. Once the kiln has cooled, charcoal can be collected. The main advantage of this type of kiln is that it can easily be carried out at the operating site. The disadvantages are that charring takes long time and the process requires constant attention.

\section{Traditional Improved Kiln (TIK)}

It has a horizontal shape with a triangular or elliptical base. It differs mainly from the traditional kiln with the following specifications:

- the wood is sorted in thicknesses;

- loading is based on double ventilation;

- the cover is made of a mixture of earth, sawdust and grass;

- ventilation holes are on the sides of the kiln and funnel is at the back of the kiln. For a load of 15 tons, a charcoal-making cycle takes 15 days.

\section{Casamance Kiln (CK)}

This kiln contains a funnel that can be made of metal barrels whose function is to improve the control of air flow. The heat flow does not escape completely from the kiln but is partially redirected to circulate within the kiln; hence the pyrolysis is ameliorated. Thanks to this "reintroduction" of heat, the charcoal-making is faster and more uniform than in traditional kiln. The main advantage of this type of kiln is its efficiency and the reduction in charcoal-making time due to its better heat circulation. The main disadvantage is the high cost of construction and running.

\section{Determination of moisture content and apparent density}

The determination of the moisture content was carried out in accordance with the NF EN 14774 (AFNOR, 2010a). The five samples used for chemical analysis. For this purpose, each sample, which was previously grinded, was separated into two parts. All these samples were then labelled and stored in polyethylene bags for laboratory analysis.

The pyrolysis cycle lasted for 10 days in the traditional and improved traditional kilns, and 7 days in the Casamance kiln. to determine the moisture content were weighed to an accuracy of $0.01 \mathrm{~g}$, dried during $48 \mathrm{~h}$ to a constant mass in a drying oven at $103^{\circ} \mathrm{C}$ and reweighed.

The moisture content was determined based on dry mass. Apparent density was determined in accordance with the NBR 11941 (Brazilian Association of Technical Standards, 2003). The five samples prepared for this pur- 
pose were first immersed in water for $24 \mathrm{~h}$. The volume of each sample was then determined by using the hydrostatic method (Rosário da Silva e Silva et al., 2018).

\section{Chemical composition of charcoal}

The samples were crushed in the porcelain mortar using a pestle. A set of sieves from 2 to $200 \mu \mathrm{m}$ was used for separation and classification. Charcoal fractions with diameters less than $0.2 \mathrm{~mm}$ were used for chemical analyses. These analyses were carried out with fives replicates of each species. A $105^{\circ} \mathrm{C}$ drying oven was used to dry samples and determine their moisture content and dry mass. The volatile matter content was determined according to the NFEN 15148 (AFNOR, 2010b) in a muffle furnace at $950^{\circ} \mathrm{C}$ by placing the crucibles for $2 \mathrm{mn}$ on the outer edge of the furnace $\left(300^{\circ} \mathrm{C}\right)$ and then for $3 \mathrm{mn}$ on the edge of the furnace $\left(500^{\circ} \mathrm{C}\right)$. The crucibles were then moved to the back of the furnace for $6 \mathrm{mn}$ with the muffle door closed. The ash content was quantified in accordance with the NFEN 14775 (AFNOR, 2010c) which requires that the crucibles be placed in the muffle furnace at $750^{\circ} \mathrm{C}$ for $6 \mathrm{~h}$. The fixed carbon content is derived after determining the moisture content of the charcoal, the volatile matter index and the ash content. All weights were taken with an accuracy of $0.01 \mathrm{~g}$. The moisture content and chemical components were calculated based on the dry mass of the charcoal (Godjo et al., 2015).

\section{Determination of the Higher Heating Value}

The higher heating values (HHV) were measured according to ASTM D 5865 ASTM, 2012) using an XRY-1A+ brand electronic oxygen calorimeter bomb on $1 \mathrm{~g}$ of sample previously dried in the oven for $48 \mathrm{~h}$ to a constant mass in a oven at $103^{\circ} \mathrm{C}$.

After the firing and balancing of the assemblage, the temperature variation was measured using a thermocouple. Before the measurements, the calorimeter water value was calibrated with pure benzoic acid of known calorific value $26.463 \mathrm{MJ} / \mathrm{kg}$. The HHV results are expressed in megajoules per kilogram of $100 \%$ dry charcoal.

\section{Statistical analysis}

The collected data were tested for normality and homogeneity of variance by Shapiro-Wilks and F tests at 5\% significance, respectively. Thereafter, effects of kiln type and wood species on each property was analysed using a two-way analysis of variance. Pairwise Wilcox test was then performed at $5 \%$ for comparison between the kiln type and wood species. Average values of the properties were compared to FAO standards (1985). According to Reynaud and Maley (1994), box plots are powerful graphical representations that give an overview and numerical summary of a data set distribution. Therefore, box plots were produced to support analyses of the charcoal variability among and within kiln and wood species. All statistical analyses were carried out using the R software (R Core Team, 2018).

\section{Results and discussion}

\section{Influence of the species and carbonization technique on the physical properties of charcoal}

\section{Variability of moisture content}

The moisture content of charcoal differ significantly among species and type of kilns used (table I). Charcoal from Movingui produced in the Casamance kiln had the lowest moisture content (4.03\%). Likewise, in the other kilns its moisture content was the lowest (table II, figure 2). All the values of moisture content of charcoal investigated remained below $10 \%$, which is the maximum threshold for charcoal intended for domestic use according to the FAO standards (FAO, 1985). The differences observed between the wood species could be related by their anatomical characteristics (table III). The lower the density, the higher the moisture content. Nko'o Abuiboto (2015) showed that charcoals produced experimentally from three African species, namely Dibetou (Lovoa trichilioides Harms: $0.53 \mathrm{~g} / \mathrm{cm}^{3}$ ), Iroko (Milicia excelsa: $0.64 \mathrm{~g} / \mathrm{cm}^{3}$ ) and Moabi (Baillonella toxisperma: $0.87 \mathrm{~g} / \mathrm{cm}^{3}$ ), have moisture contents of $7 \%$, $6 \%$ and $4 \%$, respectively. In fact, when the charring is well

Table I.

Results of the homogeneity test of the variances of average moisture contents and apparent densities of charcoals between the three wood species and the three types of kilns.

\begin{tabular}{|c|c|c|c|c|}
\hline Study properties & Sources of variation & Degree of freedom & F-value & P-value \\
\hline \multirow{4}{*}{ Moisture content } & Kilns & 2 & 9.17 & $0.000191 * * *$ \\
\hline & Species & 2 & 276.63 & $<2 \mathrm{e}-16^{\star \star \star}$ \\
\hline & Kilns x species & 4 & 18.57 & 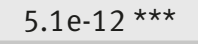 \\
\hline & Residues & 126 & & \\
\hline \multirow[t]{4}{*}{ Apparent density } & Kilns & 2 & 7.55 & $0.000798 * * \star$ \\
\hline & Species & 2 & 261.24 & 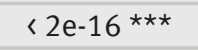 \\
\hline & Kilns $x$ species & 4 & 1.487 & 0.210073 \\
\hline & Residues & 126 & & \\
\hline
\end{tabular}


Table II.

Physical and chemical properties of charcoal produced from three selected wood species, Ayous (Triplochiton scleroxylon), Frake (Terminalia superba) and Movingui (Distemonanthus benthamianus) residues in the three types of kilns (TK, ITK and CK mean: traditional kiln, improved traditional kiln and Casamance kiln).

\begin{tabular}{|c|c|c|c|c|c|}
\hline \multirow{2}{*}{ Properties } & \multirow{2}{*}{$\begin{array}{l}\text { Type } \\
\text { of kiln }\end{array}$} & \multirow{2}{*}{$\begin{array}{l}\text { Number } \\
\text { of samples }\end{array}$} & & Wood species & \\
\hline & & & $\begin{array}{c}\text { Ayous } \\
\text { Triplochiton } \\
\text { scleroxylon }\end{array}$ & $\begin{array}{c}\text { Frake } \\
\text { Terminalia } \\
\text { superba }\end{array}$ & $\begin{array}{c}\text { Movingui } \\
\text { Distemonanthus } \\
\text { benthamianus }\end{array}$ \\
\hline \multirow[t]{3}{*}{ Moisture content (\%) } & TK & 15 & $8.06 \pm 0.84^{\mathrm{Aa}}$ & $7.77 \pm 0.66^{\mathrm{Aa}}$ & $5.94 \pm 0.87^{\mathrm{Ba}}$ \\
\hline & ITK & 15 & $7.48 \pm 0.53^{\mathrm{Ab}}$ & $7.47 \pm 0,63^{\mathrm{Aa}}$ & $5.40 \pm 0.65^{\mathrm{Ba}}$ \\
\hline & CK & 15 & $8.45 \pm 0.53^{\mathrm{Aa}}$ & $7.75 \pm 0.40^{\mathrm{Ba}}$ & $4.03 \pm 0.40^{\mathrm{cb}}$ \\
\hline \multirow[t]{3}{*}{ Apparent density $\left(\mathrm{g} / \mathrm{cm}^{3}\right)$} & TK & 15 & $0.25 \pm 0.02^{\mathrm{Aa}}$ & $0.29 \pm 0.02^{\mathrm{Ba}}$ & $0.38 \pm 0.04^{\mathrm{Ca}}$ \\
\hline & ITK & 15 & $0.25 \pm 0.02^{\mathrm{Aa}}$ & $0.29 \pm 0.03^{\mathrm{Ba}}$ & $0.42 \pm 0.05^{\mathrm{cb}}$ \\
\hline & CK & 15 & $0.27 \pm 0.02^{\mathrm{Aa}}$ & $0.31 \pm 0.01^{\mathrm{Ba}}$ & $0.42 \pm 0.05^{\mathrm{cb}}$ \\
\hline \multirow[t]{3}{*}{ Volatile Matter content (\%) } & TK & 18 & $49.39 \pm 1.65^{\mathrm{Aa}}$ & $38.31 \pm 1.65^{\mathrm{Ba}}$ & $34.69 \pm 1.62^{\mathrm{Ca}}$ \\
\hline & ITK & 18 & $36.07 \pm 3.23^{\mathrm{Aa}}$ & $30.54 \pm 3.84^{\mathrm{Bb}}$ & $22.50 \pm 3.00^{\mathrm{cb}}$ \\
\hline & CK & 18 & $29.46 \pm 1.71^{\mathrm{Aa}}$ & $24.84 \pm 2.52^{\mathrm{Bb}}$ & $20.32 \pm 1.03^{\mathrm{Bc}}$ \\
\hline \multirow[t]{3}{*}{ Fixed Carbon content (\%) } & TK & 18 & $39.00 \pm 1.7^{\mathrm{Aa}}$ & $50.30 \pm 1.72^{\mathrm{Ba}}$ & $57.25 \pm 1.65^{\mathrm{Ca}}$ \\
\hline & ITK & 18 & $52.66 \pm 3.09^{\mathrm{Ab}}$ & $58.39 \pm 3.79^{\mathrm{Bb}}$ & $70.97 \pm 2.00^{\mathrm{cb}}$ \\
\hline & CK & 18 & $59.12 \pm 2.07^{A c}$ & $63.63 \pm 3.44^{\mathrm{Bc}}$ & $74.95 \pm 0.31^{\mathrm{cc}}$ \\
\hline \multirow[t]{3}{*}{ Ash content (\%) } & TK & 18 & $3.55 \pm 0.69^{\mathrm{Aa}}$ & $3.61 \pm 0.73^{\mathrm{Aa}}$ & $2.12 \pm 0.67^{\mathrm{Ba}}$ \\
\hline & ITK & 18 & $3.46 \pm 0.99^{\mathrm{Aa}}$ & $3.58 \pm 0.93^{\mathrm{Aa}}$ & $2.07 \pm 0.55^{\mathrm{Ba}}$ \\
\hline & CK & 18 & $3.17 \pm 1.04^{\mathrm{Aa}}$ & $3.78 \pm 1.58^{\mathrm{Aa}}$ & $1.27 \pm 0.16^{\mathrm{Bb}}$ \\
\hline \multirow[t]{3}{*}{ Higher Heating Value (MJ/kg) } & TK & 18 & $27.95 \pm 3.12^{\mathrm{Aa}}$ & $23.02 \pm 4.01^{\mathrm{Ba}}$ & $26.20 \pm 0.43^{\mathrm{Aa}}$ \\
\hline & ITK & 18 & $30.03 \pm 0.94^{\mathrm{Ab}}$ & $26.62 \pm 3.52^{\mathrm{Bb}}$ & $28.99 \pm 0.49^{\mathrm{Ab}}$ \\
\hline & CK & 18 & $32.51 \pm 1.25^{\mathrm{Ac}}$ & $28.85 \pm 4.31^{\mathrm{Bc}}$ & $30.02 \pm 0.10^{\mathrm{Bb}}$ \\
\hline
\end{tabular}

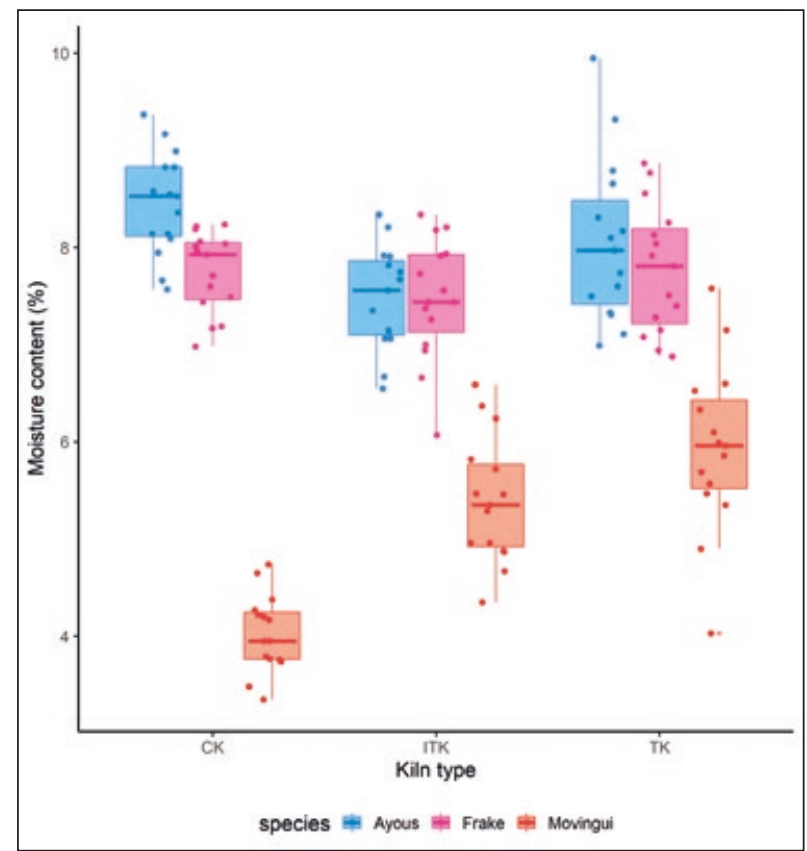

Figure 2.

Variation of moisture content of charcoal among the three wood species and three types of kiln. TK, ITK and CK mean the following: traditional kiln, improved traditional kiln and Casamance kiln, respectively. controlled, charcoal contains about $1 \%$ of moisture when it leaves the kiln (Avom, 2004). Due to its hydrophilic nature, it can quickly reabsorb moisture from the atmosphere, resulting in an irreversible water absorption that ranges from 5 to $10 \%$ depending on the species (FAO, 1985). In addition, the lowest moisture content obtained in the Casamance kiln could be explained by the quality of carbonization, which is faster and more uniform in this type of kiln, due to better air circulation in the combustion chamber, than in the two other types of kilns (Júnior et al., 2015; GIZ-HERA, 2020).

\section{Variability of apparent densities}

As for moisture content, the apparent densities of charcoal differ significantly among species and kiln type (table I). Comparatively, charcoal from Movingui is denser (table II, figure 3). This result could be explained by its anatomical structure (Gomes et al., 2007; Brand et al., 2015), as Movingui is a medium-heavy wood with a density of $0.7 \mathrm{~g} / \mathrm{cm}^{3}$ compared to the other two woods species which are light woods (table III). In addition, the highest density $\left(0.42 \mathrm{~g} / \mathrm{cm}^{3}\right)$ of charcoal produced in the Casamance kiln and the improved traditional kiln, suggests a significant effect of the carbonization technique, which are faster and more uniform in these two types of kilns (GIZ-HERA, 2020). Similar differences were also found in Senegal with charcoal from Eucalyptus produced in the Casamance kiln and the metal kiln (Ndour, 1986). 
Table III.

Characteristics of the wood species used for charcoal production.

\begin{tabular}{|l|l|c|c|}
\hline $\begin{array}{l}\text { Commercial } \\
\text { name }\end{array}$ & $\begin{array}{l}\text { Scientific } \\
\text { name }\end{array}$ & $\begin{array}{c}\text { Wood density } \\
\left(\mathbf{g} / \mathbf{c m}^{3} \mathbf{)}\right.\end{array}$ & Qualification \\
\hline Ayous & Triplochiton scleroxylon & $0.38 \pm 0.05$ & Very light wood \\
\hline Frake & Terminalia superba & $0.54 \pm 0.07$ & Light wood \\
\hline Movingui & Distemonanthus benthamianus & $0.73 \pm 0.06$ & Medium wood \\
\hline
\end{tabular}

species, particularly their level of liquid and tarry residues. Indeed, it has been shown that the denser the wood, the lesser its volatile matter content (Nko'o Abuiboto, 2015). The differences observed between the kilns could therefore be attributed to the degree of burning, precisely the final temperatures reached during the pyrolysis reaction (Assis et al., 2016). Ndour (1986) found similar results on charcoal from Euca-

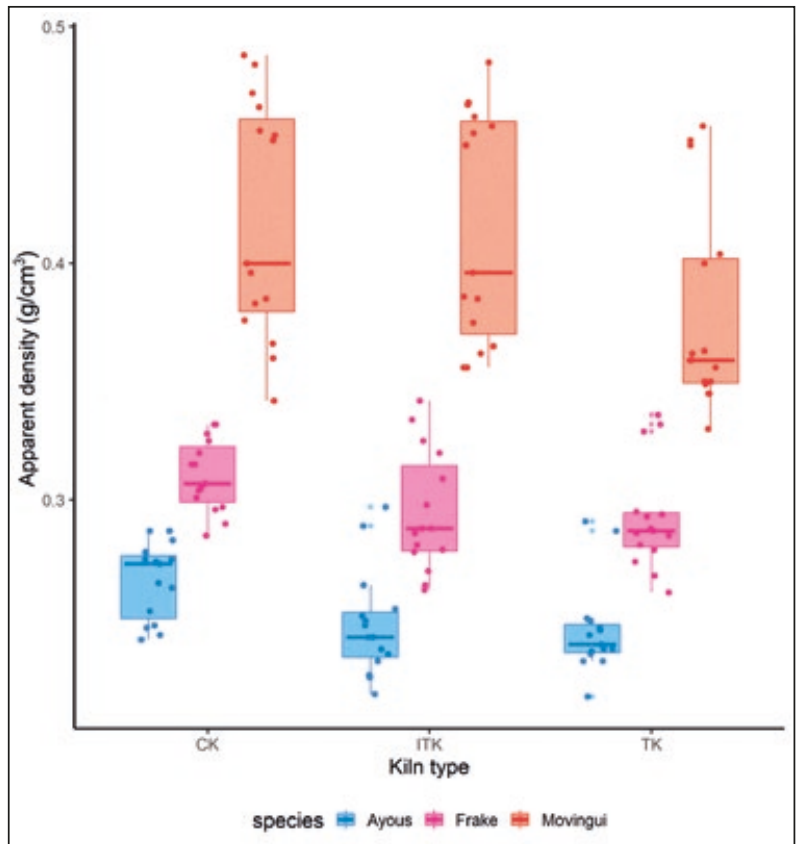

Figure 3.

Variation of apparent density of charcoal among the wood species and the three types of kiln. TK, ITK and CK mean the following: traditional kiln, improved traditional kiln and Casamance kiln, respectively.

\section{Influence of carbonization technique and the species on chemical properties of charcoal}

Table IV shows that the volatile matter content, ash content and fixed carbon content vary significantly among wood species and types of kilns. In table II, the lowest volatile matter content (20.32\%), ash content (1.27\%) and the highest fixed carbon content $(74.95 \%)$ are obtained with charcoal from Movingui produced in the Casamance kiln. The differences between species and kiln types can also be explained by the anatomical characteristics of the wood used (Gomes et al., 2007; Brand et al., 2015) and the quality of the pyrolysis in the kiln (GIZ-HERA, 2020).

\section{Variability of volatile matter content}

Among the three wood species, Movingui charcoal obtained from Casamance kiln had the lowest volatile matter content $(20.32 \%)$. The most possible explanation could be related to the chemical composition of the wood of these lyptus produced from the Casamance kiln (22.9\%) and the metal kiln (30.1\%). In addition, for domestic use it is only the charcoal produced in the Casamance kiln that satisfy FAO's standards (FAO, 1985).

In addition, charcoals produced in the Casamance kiln are the only ones that satisfy FAO's standards (FAO, 1985), from good charcoal for domestic use.

\section{Variability of the ash content}

The results from the various ash content test show that Movingui charcoal produced in the Casamance kiln has the lowest ash content (1.27\%). These differences can be explained by the proportion of inorganic compounds in each species (Badea et al., 2008). This finding is supported by Mensah et al. (2017) who found ash contents of $2.1 \%$ to $2.9 \%$ in charcoals produced from some plantation species in Ghana. Girard (2002) also found an average ash content between 3.1 to $5.8 \%$ with charcoal from Eucalyptus produced with the traditional kiln and Nko'o Abuiboto (2015) found that the average ash contents are between $1.4 \%$ and $8.8 \%$ in three African species (Dibetou, L. trichilioides Harms, Iroko, M. excelsa and Moabi, B. toxisperma).

\section{Variability of fixed carbon content}

The highest fixed carbon content (74.95\%) was obtained with charcoal from Movingui produced in the Casamance kiln (table II, figure 4). This result highlights the influence of the carbonization process on the residual fixed carbon content of charcoal (Ndour, 1986). Briane and Haberman (1984) also showed that the fixed carbon content of charcoals increases with the carbonization temperature. This parameter is also influenced by the species (Nko'o Abuiboto, 2015).

\section{Variability of the Higher Heating Value}

The higher heating value (HHV) of the charcoal differs significantly between woods species and kiln types (table II). On comparing the kilns, the highest HHV value (32.51 MJ/ $\mathrm{Kg}$ ) was obtained with charcoal from Ayous. In addition, this value was observed in the Casamance kiln. Although there are no standards that specify the HHVs of commercial charcoals, Girard (2002) showed that the higher heating values of Eucalyptus vary between 28.6 and $32.6 \mathrm{MJ} / \mathrm{kg}$. Ndour (1986) obtained similar results for this species with charcoal produced in the metal and the Casamance kilns: 26.6 and $31.8 \mathrm{MJ} / \mathrm{kg}$. The HHV obtained with charcoal from Ayous, a lightwood species, in the Casamance kiln reflects its abi- 


\begin{tabular}{|c|c|c|c|c|}
\hline \multicolumn{5}{|c|}{$\begin{array}{l}\text { Table IV. } \\
\text { Results of the ANOVA test on the chemical properties and the higher heating value of the charcoal obtained } \\
\text { among the three types of kilns and the studied wood species. }\end{array}$} \\
\hline Study properties & $\begin{array}{l}\text { Sources } \\
\text { of variation }\end{array}$ & $\begin{array}{c}\text { Degree } \\
\text { of freedom }\end{array}$ & F-value & P-value \\
\hline \multirow[t]{4}{*}{ Volatile Matter content } & Kilns & 2 & 615.2 & $<2 \mathrm{e}-16 * \star \star$ \\
\hline & Species & 2 & 361.0 & 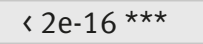 \\
\hline & Kilns x species & 4 & 13.5 & $1.9 \mathrm{e}-09 * \star \star$ \\
\hline & Residues & 153 & & \\
\hline \multirow[t]{5}{*}{ Fixed Carbon content } & Kilns & 2 & 701.86 & $<2 \mathrm{e}-16^{\star \star \star \star}$ \\
\hline & Species & 2 & 708.43 & $<2 \mathrm{e}-16^{\star \star \star}$ \\
\hline & Kilns $x$ species & 4 & 12.18 & $1.27 \mathrm{e}-08 * \star \star$ \\
\hline & Residues & 126 & & \\
\hline & Kilns & 2 & 2.471 & 0.0879 \\
\hline \multirow[t]{4}{*}{ Ash content } & Species & 2 & 66.966 & $<2 \mathrm{e}-16 * \star \star$ \\
\hline & Kilns x species & 4 & 1.912 & 0.1112 \\
\hline & Residues & 126 & & \\
\hline & Kilns & 2 & 46.248 & $<2 \mathrm{e}-16 * \star \star$ \\
\hline \multirow[t]{3}{*}{ Higher Heating Value (HHV) } & Species & 2 & 32.752 & $1.45 \mathrm{e}-12 * \star \star$ \\
\hline & Kilns x species & 4 & 0.989 & 0.416 \\
\hline & Residues & 126 & & \\
\hline
\end{tabular}
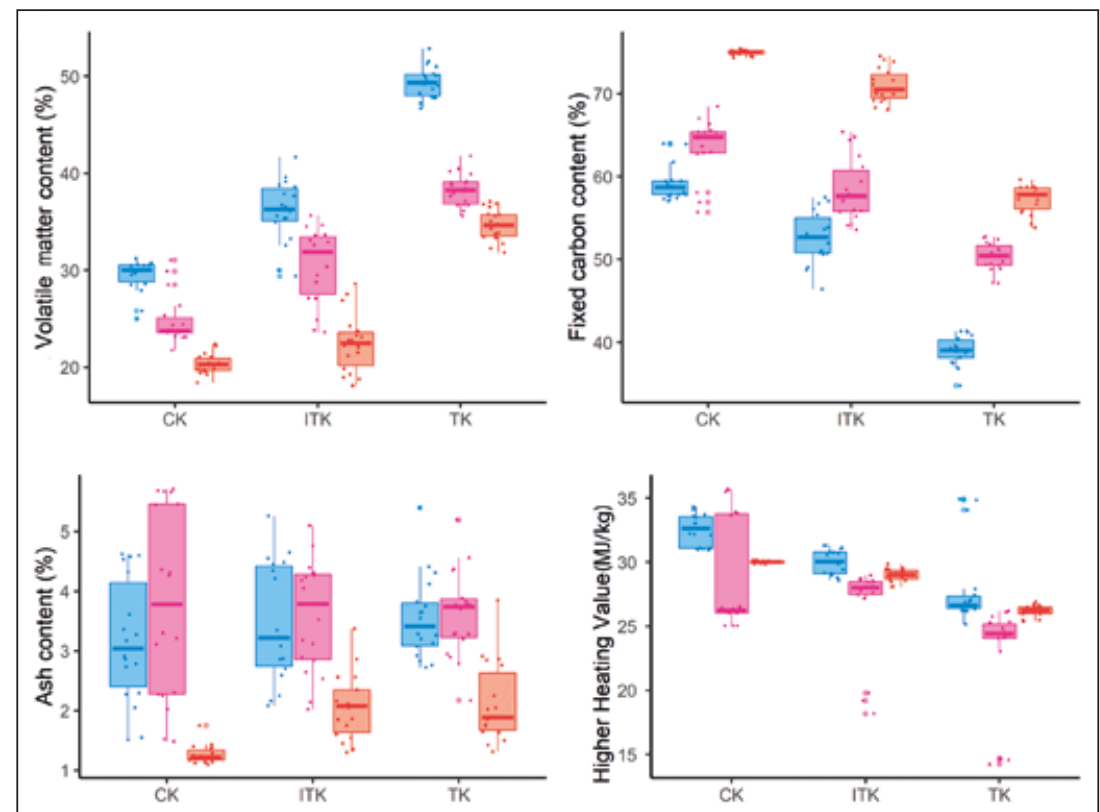

species $\risingdotseq$ Ayous $\risingdotseq$ Frake $\risingdotseq$ Movingui

species $\risingdotseq$ Ayous $\risingdotseq$ Frake $\risingdotseq$ Movingul

Figure 4.

Variation of chemical content and higher heating value (HHV) of charcoal among the three wood species and the three types of kiln. Ayo, Fra and Mov mean: Ayous, Frake and Movingui and TK, ITK and CK mean: traditional kiln, improved traditional kiln and Casamance kiln, respectively. lity to release a large amount of thermal energy by combustion as a hardwood. Adegoke et al. (2014) found similar results with this species (32.79 MJ $/ \mathrm{kg}$ ) as well as for another light-wood species namely Frake (T. superba, 32.69 MJ/kg). These results indicate that the HHV of charcoal is mainly influenced by the type of kiln used, rather than the wood species (Ndour, 1986).

\section{The singularity of Ayous charcoal}

Charcoal from Ayous (T. scleroxylon) has the lowest density $\left(0.25 \mathrm{~g} / \mathrm{cm}^{3}\right)$ and the highest $\mathrm{HHV}(32.51 \mathrm{MJ} / \mathrm{kg})$. This HHV could be related to its porous structure and chemical composition. Zeng et al. (2015) found that large pores are associated with a high reactivity, or combustibility and thus the best combustion performance. Similarly, these authors noted that the volatile matter is a significant fraction of the higher heating value of charcoal. Tillman (2000) also showed that the ratio of the volatile matter to fixed carbon (VM/FC) is a good indicator of the charcoal reactivity. According to this author, a charcoal with good reactivity has a VM/FC ratio greater than 1 . The maximum value obtained with charcoal from Ayous is 1.29 , which reflects its a very good reactivity. 


\section{Conclusion}

The objective of this study was to assess the variability of the physical and chemical properties of charcoals produced from industrial sawmill residues in the eastern region of Cameroon using three different carbonization technologies (traditional kiln, improved traditional kiln and Casamance kiln) and three wood species namely: Ayous (Triplochiton scleroxylon), Frake (Terminalia superba) and Movingui (Distemonanthus benthamianus). Physical and chemical properties determined are moisture content, apparent density, volatile matter content, fixed carbon content, ash content and Higher Heating Value. Our results show that properties of charcoal are strongly influenced by the species and the type of kiln used. Movingui, with the highest density $\left(0.73 \mathrm{~g} / \mathrm{cm}^{3}\right)$, provided charcoal with the lowest moisture content (4.03\%) and a highest apparent density $\left(0.42 \mathrm{~g} / \mathrm{cm}^{3}\right)$. The lowest volatile matter (20.32\%), the lowest ash content (1.27\%) and the highest fixed carbon content (74.95\%) were also obtained with this species. All the properties of charcoals investigated are better in the Casamance kiln, certainly due to the quality of pyrolysis, which is faster and more uniform in this kiln than in the other types.

The singularity of charcoal from Ayous, which shows a highest HHV $(32.5 \mathrm{MJ} / \mathrm{kg})$, reflects its ability to release a large amount of thermal energy by combustion. This high reactivity offers good energy expectation of this species for cooking and establishes the energy efficiency of some lightwoods, which are sometimes wrongly considered inappropriate for the production of charcoal. This result is also very interesting in the current context of Cameroon because Ayous is the most exploited species in the country, with annual log volumes of more than $800,000 \mathrm{~m}^{3} /$ year, representing $34.84 \%$ of national log production. As the yield material of the sawmills in Cameroon is $30 \%$, the valorization of the large residual biomass generated by this species as biofuel could represent an enormous energy potential, which could contribute to reduce the pressure on forest ecosystems.

In addition, the results obtained in this study also support the government's position that promotes the use of sustainably produced charcoal from industrial sawmill residues instead of charcoal from felling trees, and reassure consumers about their technological characteristics. Indeed, in 2012, the Government of Cameroon took a decision (Decision No. 2032/D/MINFOF of 22 August 2012) that specifies special products of economic interest to the country whose commercial exploitation is conditional on obtaining a prior operating permit. In order to encourage the use of sustainably produced charcoal, exemption from the scope of this decision and from prior authorisation for its production and marketing is given to charcoal from sawmill residues.

Finally, the present study thus opens interesting perspectives to investigate other tropical woods that are currently exploited to promote their potentials for the production of charcoal.

\section{Acknowledgement}

The authors are grateful to all the charcoal producers of the Eastern Cameroon and Dieudonné Kemmegne for his help in gathering the extensive data sets used in this manuscript.

\section{References}

Adegoke O. A., Fuwape J. A., Fabiyi J. S., 2014. Combustion properties of some tropical wood species and their pyrolytic products characterization. Energy and Power, 4 (3): 54-57. http://article.sapub. org/10.5923.j.ep.20140403.02.html

AFNOR, 2010a. Bois combustibles solides. Méthode de détermination de la teneur en humidité (NF EN 14774).

AFNOR, 2010b. Bois combustibles solides. Méthode de détermination de la teneur en matières volatiles (NF EN 15148).

AFNOR, 2010c. Bois combustibles solides. Méthode de détermination de la teneur en cendres (NF EN 14775).

Assis M. R., Brancheriau L., Napoli A., Trugilho P. F., 2016. Factors affecting the mechanics of carbonized wood: literature review. Wood Science and Technology, 50: 519-536. https://doi.org/10.1007/ s00226-016-0812-6

ASTM, 2012. Standard test method for gross calorific value of coal and coke (D5865). https://www.astm.org/Standards/D5865.htm

Avom J., 2004. Contribution de la valorisation de l'Ayous, de l'Akom et des rafles de régimes de palme : carbonisation-activation-propriétés absorbantes-application au traitement des eaux. Thèse de doctorat d'État, Faculté des sciences de l'Université de Yaoundé I, Cameroun, 220 p.

Badea A., Gheorghe C., Mărculescu C., Apostol T., 2008. L'influence des propriétés physiques et des paramètres du processus sur les produits de pyrolyse. Scientific Bulletin-University Politehnica of Bucharest, Series C. 70 (2) : 103-110. https://www.scientificbulletin.upb.ro/rev_docs_arhiva/full28190.pdf

Brand M., Rodrigues A., Oliveira Árvore A., Machado M., 2015. Quality of charcoal for domestic consumption marketed in the Southern Highlands Region of Santa Catarina. Revista Árvore 39 (6). https:// doi.org/10.1590/0100-67622015000600020

Brazilian Association of Technical Standards (ABNT), 2003. Wood Determination of basic density (NBR 11941). Brasil, Associação Brasileira de Normas Técnicas (ABNT). http://www.abnt.org.br/

Briane D., Haberman A., 1984. Base expérimentale de carbonisation de Saint-Martin de Londres : essais comparatifs de six systèmes de carbonisation artisanale. Paris, AFME, Aix-en-Provence, Association Bois de Feu, $188 \mathrm{p}$.

Doat J., 1977. Le pouvoir calorifique des bois tropicaux. Bois et Forêts des Tropiques. 172 : 33-55. https://revues.cirad.fr/index. $\mathrm{php/BFT/article/view/19325}$

Eba'a Atyi R., Lescuyer G., Ngouhouo Poufoun J., Moulendè Fouda T., 2013. Étude de l'importance économique et sociale du secteur forestier et faunique au Cameroun. Rapport final. Bogor, Indonésie, CIFOR, 315 p. http://www.minfof.cm/documentation/Etude_MINFOF 2013.pdf

FAO, 1985. Industrial charcoal making-quality control of charcoal and by products. Rome, Italy, FAO, FAO Forestry Paper 63, $142 \mathrm{p}$. http://www.fao.org/3/x5555e/x5555e.pdf

FAO, 2017. Incentivizing sustainable wood energy in Sub-Saharan Africa. Rome, Italy, FAO, 11 p. http://www.fao.org/3/a-i6815e.pdf FRM, 2018. Vision stratégique et industrialisation de la filière bois dans les 6 pays du Bassin du Congo, Horizon 2030. Rapport stratégique régional. Mauguio, France, Forêt Ressources Management, $226 \mathrm{p}$.

Girard P., 2002. Quel futur pour la production et l'utilisation du charbon de bois en Afrique ? Unasylva, 211 (53) : 30-35. http://www. fao.org/tempref/docrep/fao/005/y4450f/y4450f05.pdf 
GIZ-HERA, 2020. Cooking Energy Compendium, a practical guidebook for implementers of cooking energy interventions. https:// energypedia.info/wiki/La_Production_du_Charbon_de_Bois

Godjo T., Tagutchou J.-P., Naquin P., Gourdon R., 2015. Valorisation des coques d'anacarde par pyrolyse au Bénin. Déchets - Sciences et Techniques, 70 : 11-18. https://doi.org/10.4267/dechetssciences-techniques.3282

Gomes M. J. M., Silva M. L., Valverde S. K., Jacovine L. A. G., Soares N. O. S., Pires V. A., 2007. Diagnostic of metallurgical industry in Minas Gerais. Cerne, 13: 60-66. http://cerne.ufla.br/site/index. php/CERNE/article/view/342

Júnior A. F. D., Andrade C. R., Brito J. O., Milan M., 2015. Desdobramento da função qualidade na avaliação da qualidade do carvão vegetal utilizado para cocção de alimentos. Floresta e Ambiente, 22: 262-270. http://dx.doi.org/10.1590/2179-8087.105314

Marien J.-N., Dubiez E., Louppe D., Larzillière A., 2013. Quand la ville mange la forêt : Les défis du bois-énergie en Afrique centrale. Versailles, France, Éditions Quæ, 238 p. http://publications.cirad. fr/une_notice.php?dk=569497

Mensah L. D., Lamptey B. K., Kemausuor F., 2017. Experimental analysis of three common tree species in Ghana. International Journal of Engineering Sciences and Research Technology, 6: 133-141. http://www.ijesrt.com/issues\%20pdf\%20file/Archive-2017/June2017/18.pdf

Miguiri B., Wirba I., Zaida J., Vondou D., Mouangue R., 2020. Thermal characterization of local tropical woods in view of their valorization. Journal of Materials and Environmental Science, 11 (5): 759-771. https://www.jmaterenvironsci.com/Document/vol11/vol11_N5/ IMES-2020-1168-Miguiri.pdf

Mouangue R., Ngako S., Tégawendé Zaida J., Kuitche A., 2020 Heavy Fuel Oil Combustion in a Ciment Rotary Kiln: Measurement and Modelling. Journal of the International Flame Research Foundation, Industrial Combustion, 17: 1-26. https://ifrf.net/research/ archive/heavy-fuel-oil-combustion-in-a-cement-rotary-kiln-measurement-and-modelling/

Nasi R., Billand A., van Vliet N., 2012. Managing for timber and biodiversity in the Congo Basin. Forest Ecology and Management, 268: 103-111. https://doi.org/10.1016/i.foreco.2011.04.005

Ndour B., 1986. Essai de carbonisation du bois et de la tourbe en four métallique transportable. Analyse du produit final. Dakar, Sénégal, Institut sénégalais de recherches agricoles, Centre national de recherches forestières, 80 p. http://intranet.isra.sn/greenstone/ collect/tmisra/index/assoc/HASH0185.dir/doc.pdf

Nguenang G. M., Ngo Badjeck M., 2013. Valorisation énergétique par la carbonisation des rebuts d'exploitation. Expériences menées dans deux sites forestiers à l'Est-Cameroun : SFID et GRUMCAM. Conférence Gestion durable de la ressource bois énergie en RDC et au Congo Brazzaville, 11-13 juin 2013, Kinshasa (RDC). http:// projets.cirad.fr/content/download/12502/75099/file/Carbonisation $\% 20$ des $\% 20$ rebuts $\% 20$ d'exploitation\%20(Cameroun)\%20 (M.\%20Ngo\%20Badjeck\%20\&\%20G.\%20M.\%20Nguenang).pdf

Nko'o Abuiboto M., 2015. Étude des propriétés physico-chimiques des charbons obtenus après activation chimique des résidus ligneux du Dibetou, de l'Iroko et du Moabi. Thèse de doctorat, Faculté des sciences de l'Université de Yaoundé I, Cameroun, 125 p.

R Core Team, 2018. R: A language and environment for statistical computing. Vienna, Austria, R Foundation for Statistical Computing. https://www.R-project.org/.

Reynaud I., Maley J., 1994. Histoire récente d'une formation forestière du Sud-Ouest-Cameroun à partir de l'analyse pollinique. Comptes-Rendus de l'Académie des Sciences, Série 3, Sciences de la vie, 317 : 575-580.

Rosa R. U. A., Arantes M. D. C., Paes J. B., Andrade W. S. D. P., Moulin J. C., 2012. Quality of charcoal for domestic consumption. Revista Árvore, 3: 41-48.

Rosário da Silva e Silva M., Dos Santos Ribeiro E. A., Barbosa J. P., Alves Júnior F. T., Guedes M. C., Pinheiro P. G., et al., 2018. Quality attributes of commercial charcoals produced in Amapá, a Brazilian state located in the Amazonia. Environment, Development and Sustainability, 22: 719-732. https://doi.org/10.1007/s10668018-0216-x
Schure J., Marien J.-N., De Wasseige C., Drigo R., Salbinato F., Dirou S., et al., 2012. Contribution du bois énergie à la satisfaction des besoins énergétiques des populations d'Afrique centrale : perspectives pour une gestion durable des ressources disponibles. In : De Wasseige $C$. , De Marcken P., Bayol N., Hiol Hiol F., Mayaux P., Desclée B., et al. (éds). Les forêts du Bassin du Congo : État des forêts 2010. Luxembourg, Office des publications de l'Union européenne, 109-122. https://www. observatoire-comifac.net/docs/edf2010/FR/Etat-des-forets 2010.pdf Schure J., Assembe-Mvondo S. A., Awono A., Ingram V., Lescuyer G., Sonwa D., Somorin O., 2010. L'état de l'art du bois énergie en RDC : Analyse institutionnelle et socio-économique de la filière bois énergie. Yaoundé, Cameroun, Cifor, 103 p. https://agritrop.cirad. fr/566698/

Tchouanti Nzali B., Onguene Mvogo P., Ali A., Mouangue R., 2019. Effect of particle size on syngas production using sawdust of Cameroonian Triplochiton scleroxylon. Scientific African, 12 p. https:// doi.org/10.1016/i.sciaf.2019.e00182

Tillman D. A., 2000. Biomass cofiring: The technology, the experience, the combustion consequences. Biomass and Bioenergy, 19: 365-384. http://doi.org/10.1016/s0961-9534(00)00049-0.

Zeng K., Minh D. P., Gauthier B., Weiss-Hortala E., Nzihou A., Flamant G., 2015. The effect of temperature and heating rate on char properties obtained from solar pyrolysis of beech wood. Bioresource Technology, 182: 114-119. https://doi.org/10.1016/i. biortech.2015.01.112

\begin{tabular}{|c|c|}
\hline Rôle du contributeur & Noms des auteurs \\
\hline Conceptualisation & $\begin{array}{l}\text { J. Zobo Mfomo, A. B. Biwolé, } \\
\text { E. F. Fedoung }\end{array}$ \\
\hline Gestion des données & $\begin{array}{l}\text { J. Zobo Mfomo, A. B. Biwolé, } \\
\text { E. F. Fedoung }\end{array}$ \\
\hline Analyse formelle & J. Zobo Mfomo, A. B. Biwolé \\
\hline $\begin{array}{l}\text { Acquisition du } \\
\text { financement }\end{array}$ & D. Hubert, H. Ducenne \\
\hline $\begin{array}{l}\text { Enquête et } \\
\text { investigation }\end{array}$ & G. T. Ekassi \\
\hline Méthodologie & J. Zobo Mfomo, A. B. Biwolé \\
\hline Gestion de projet & J. Zobo Mfomo \\
\hline Ressources & $\begin{array}{l}\text { D. Hubert, H. Ducenne, R. Mouangue, } \\
\text { A. B. Biwolé }\end{array}$ \\
\hline Logiciels & A. B. Biwolé \\
\hline Supervision & J. Zobo Mfomo \\
\hline Validation & $\begin{array}{l}\text { J. Zobo Mfomo, A. B. Biwolé, } \\
\text { E. Fo. Fedoung }\end{array}$ \\
\hline Visualisation & J. Zobo Mfomo, A. B. Biwolé \\
\hline $\begin{array}{l}\text { Écriture - Préparation } \\
\text { de l'ébauche originale }\end{array}$ & J. Zobo Mfomo \\
\hline $\begin{array}{l}\text { Écriture - Révision } \\
\text { et édition }\end{array}$ & $\begin{array}{l}\text { J. Zobo Mfomo1, A. B. Biwolé, } \\
\text { E. F. Fedoung, G. T. Ekassi, D. Hubert, } \\
\text { H. Ducenne, R. Mouangue }\end{array}$ \\
\hline
\end{tabular}

Bois et Forêts des Tropiques - Revue scientifique du Cirad (c) Bois et Forêts des Tropiques (c) Cirad

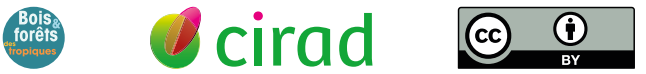

Cirad - Campus international de Baillarguet, 34398 Montpellier Cedex 5, France - Contact : bft@cirad.fr - ISSN : L-0006-579X 